\title{
Not cashing in on inventions
}

SIR-Your snippet of news under the heading "A helping hand for inventors", (Nature 327, 651; 1987) states that the "BTG scored a major triumph in the defence of British patents and realized substantial royalities for the British inventors of advanced medical scanners. The US electrical conglomerate General Electric is to pay BTG an undisclosed sum, believed to be millions of dollars, in royalties occurring from the sale of scanners in the past two years. Among the beneficiaries will be the teams from Nottingham and Aberdeen Universities."

As one of the members of the Aberdeen team, I can say that the impression created that the inventors will receive large sums of money is very misleading.

Sincere congratulations to the British Technology Group for their achievement in bringing the negotiations with the US General Electric Co. to a satisfactory conclusion: it is excellent news for Britain, the three universities and their departments involved, and it is good news for the scientists - but no more than good news and "millions" will certainly not come their way. On a machine sold at $£ 750,000$, the royalty paid by the company to $\mathrm{BTG}$ might be as much as $£ 1,000$. Allowing for overheads, including expensive patenting and high legal costs, the BTG take, the three universities' take and the university departments' take, it means about $£ 5$ to each of a team of six inventors from which about half will go in income tax. If 400 scanners are sold per year, this means $£ 1,000$ for one of the inventors to spend per year. This is better than nothing and very acceptable, but the inventor will have to be the proverbial cat with at least nine lives to make a million.

Also, does this not make clear another contributory factor to the brain drain? It was a brilliant piece of hard work; it is leading to an important and genuine advance in medicine; it was a 10 -year fight to wrest the secrets from nature, to wrest the grants to make it possible against all the competition and the cuts. The BTG says in its press release that "the agreement will provide the originators of this pioneering work with financial returns commensurate with the importance of their contribution". Is the reward commensurate? One of the reasons leading to it not being so is that the patent laws in the United Kingdom are very favourable to the employer, while in the United States and West Germany they are more favourable to the inventor and less 'employer'and institution-dominated. Could this not be a contributory factor to two of my team being now in the United States, and one in West Germany? The inventor has very few rights and hardly any say in what happens to his invention. It can be sold and disposed of as company or institutional intellectual property without reference to him. Unless he can afford the very expert and expensive legal advice needed, he has no say or redress in the matter. However, we are left with the very important personal satisfaction of knowing that our salaries are coming back to Britain from abroad 20 times over per year. I hope everyone remembers that, too, in these days of university cuts.

\section{John Mallard \\ Department of Bio-Medical Physics and Bio-Engineering, \\ University of Aberdeen and Grampian Health Board, Foresterhill, Aberdeen AB92ZD, UK}

\section{Aids: another threat}

SIR-The public health threat from the AIDS (acquired immune deficiency syndrome) virus compels attention to laboratory practice. It appears' that blood and possibly other body fluids from people with AIDS can infect others, either by intact mucosa or dermal cuts. These findings demand a review of many old, often comfortable, laboratory procedures. In my laboratory, we study the feeding behaviour of medicinal leeches; their potential for acting as an AIDS vector is viewed with dismay. In feeding leeches, we routinely use human blood obtained from a hospital blood bank where it is tested for both AIDS and hepatitis virus, but all feeding experiments must now be conducted while wearing rubber gloves, as AIDS is not always detected by the antibody test.

These developments face educational institutions with new responsibilities for their students. Students of introductory physiology courses, of whom there may be 500,000 a year in US colleges, are regularly exposed to the hazards from the blood and body fluids of others. These courses usually have laboratories which require blood samples be taken with lancets. The samples are used for cell counts, blood typing and differential staining. Blood is handled repeatedly as it is poured, smeared, dabbed, washed and centrifuged. Other experiments require handling and examination of fresh saliva and urine.

The potential for viral transmission among the large numbers of students as they conduct experiments in the close confines of the teaching laboratory is frightening. The risk of accidentally exposing the oral or optic mucosa to blood during sampling and handling is genuine. The hazards to instructors who clean up discarded lancets and slides is also not inconsiderable.

We must decide whether the risks imposed by a potential exposure to deadly retrovirus are warranted by the "educational experience" of general teaching laboratories. At my university, we think not. All experiments in introductory physiology and biology courses that require students to be exposed to fresh blood, urine or saliva have now been cancelled (permanently, I suspect).

Charles M. Lent

Department of Biology,

Utah State University,

Logan, Utah 84322-5305, USA

. III International Conference on AIDS, Washington, DC 1-5 June 1987.

\section{Race relations}

SIR-Since 1948, the number of deaths worldwide from racial strife is over a thousand times the South African total; and about 1,500 million people have sham votes in one-party states against 26 million without votes in South Africa. But condemnation of South Africa is much harsher than that of other countries. Clearly, racial discord and lack of suffrage alone cannot explain the ostracism.

Many white boycotters cannot admit that they have negative feelings towards blacks: three signs of this are excessive reaction, unconscious aggression and overcompensation. Any outside stimulus that stirs up such feelings is repressed as strongly as they are, hence the quite disproportionate reaction of boycotts and sanctions. The fact that these measures hurt blacks badly shows how represssed feelings continue to act - unconsciously. The overcompensation needed to keep the feelings out of consciousness appears in such ways as 'affirmative action' (which is also aggression against blacks because it insults them).

For the sake of good race relations may at least some boycotters gain insight soon. J.A.D. EWART

Delgany,

Solesbridge Lane,

Chorleywood,

Rickmansworth, Herts WD3 5SW

\section{Immortality}

SIR-I am sorry to see John Maddox once again rubbishing the tenets of Christian belief (Nature 326, 451; 1987, "immortality is impossible").

It is not that Christians are touchy about criticism, but he might mislead the illinformed. The fact is, he does not have the data necessary to write off the 2,000-year experience of the Christian community.

It may be convenient for experimental purposes to 'exclude the principle' of this, but in so doing one can no longer make scientific statements about it.

JOHN DUDDERIDGE

49 Macaulay Road,

Luton LU4 OLN, UK 